\title{
Growth Hormone Immunoreactivity Does Not Reflect Bioactivity
}

\author{
GIORGIO RADETTI, MAURO BOZZOLA, SARA PAGANI, MARIA E. STREET, \\ AND LUCIA GHIZZONI \\ Department of Paediatrics, Regional Hospital of Bolzano, 39100 Bolzano [G.R.]; Department of \\ Paediatrics, University of Pavia, 27100 Pavia [M.B., S.P.]; and Department of Paediatrics, University of \\ Parma, 43100 Parma, Italy [M.E.S., L.G.]
} \begin{abstract}
In childhood, the largest secretory burst of GH occurs during
nighttime, and consists of a complex mixture of molecular forms of GH that are thought to have different biologic activity. Standard GH assays cannot distinguish between bioactive and biologically inactive $\mathrm{GH}$ isoforms. To examine this relationship, overnight GH secretion was assessed by blood sampling every 30 min in 10 short prepubertal children ( 7 boys and 3 girls) to evaluate both the serum concentration and the biologic activity of GH. Serum GH concentrations were measured by an immunofluorometric assay and its biologic activity by the $\mathrm{Nb} 2$ cell bioassay. The $12-\mathrm{h}(2000 \mathrm{~h}$ to $0800 \mathrm{~h})$ and $6-\mathrm{h}(2000 \mathrm{~h}$ to $0200 \mathrm{~h}$ and $0200 \mathrm{~h}$ to $0800 \mathrm{~h}$ ) $\mathrm{GH}$ profiles were analyzed using the Pulsar program. When GH secretory pattern was measured by immunofluorometric assay, the area under the curve above the 0 line, the mean GH concentration, and the mean height of the secretory peaks were significantly higher during the first than during the second part of the night $(29.17 \pm 5.93$ versus $16.29 \pm$ $1.87 \mathrm{mIU} / \mathrm{L}, p<0.05 ; 7.77 \pm 1.28$ versus $4.83 \pm 0.33 \mathrm{mIU} / \mathrm{L}$, $p<0.05 ; 4.61 \pm 0.94$ versus $2.68 \pm 0.27 \mathrm{mIU} / \mathrm{L}, p<0.05$,
\end{abstract}

$\mathrm{GH}$ bioactivity in serum is dependent on many factors, including $\mathrm{GH}$ isoforms and binding proteins. At least four different isoforms of $\mathrm{GH}(27 \mathrm{kD}, 20 \mathrm{kD}, 17 \mathrm{kD}$, and $5 \mathrm{kD})$, one or more acidic peptides, and also monomeric, dimeric, and pentameric GH aggregates of different biopotency have been identified. Furthermore, two major GH binding proteins modulate significantly $\mathrm{GH}$ availability to target tissues (1). The essential information that one wishes to gain by $\mathrm{GH}$ blood sampling is the amount of biologically active, functional $\mathrm{GH}$ in the circulation. However, analytical results provide a quantitation of immunoreactive $\mathrm{GH}$ molecular forms in the serum, to which fragments, variants, and aggregates also contribute to a variable extent depending on the specificity of the antibodies used in the assay.

Received February 22, 2000; accepted June 15, 2000.

Correspondence: Dr. Giorgio Radetti, Department of Paediatrics, Regional Hospital of Bolzano, via L Boehler n 5, 39100 Bolzano, Italy. respectively). In contrast, GH biologic activity was not significantly different during the two parts of the night. In conclusion, a dissociation between GH bioactivity and immunoreactivity is present in physiologic conditions, indicating that standard $\mathrm{GH}$ measurements do not provide any information on the biologic activity of the hormone. Although GH secretion is regulated by complex neuroendocrine mechanisms, the biologic activity of the hormone seems to be independent of them and is most probably regulated by peripheral mechanisms acting on its clearance or bioavailability to the target tissues. (Pediatr Res 48: 619-622, 2000)

Abbreviations
IGFBP-3, IGF binding protein 3
IFMA, immunofluorometric assay
Nb2, Nb2 cell bioassay
hGH, human GH
AUCb, area under the curve above baseline
AUCo, area under the curve above 0 line

GH secretion is pulsatile and regulated mainly by two hypothalamic regulatory hormones, GH releasing hormone and somatostatin. This intermittent hormone release is of physiologic importance as indicated by the asymptotic relation between the amplitude of GH pulses and growth velocity (2). Furthermore, the rate of increase of serum GH concentration during the upstroke of a GH pulse appears to be an important factor in determining the response of target organs (3). For example, in skeletal muscle in experimental conditions, pulsatile GH increases IGF-I mRNA more effectively than continuous GH infusion (4). The aim of the present study was to assess whether pulsatility is a common feature of both spontaneous immunoreactive GH secretion and GH bioactivity, and whether there is a relationship between $\mathrm{GH}$ bioactivity and immunoreactivity. Therefore, we analyzed the pulsatile properties of the 12-h nighttime immunoreactive $\mathrm{GH}$ concentrations in a group of prepubertal children affected by growth delay, and compared them with those of the biologically active hormone as determined by the $\mathrm{Nb} 2$ cell bioassay. 


\section{METHODS}

\section{Subjects}

Ten prepubertal children ( 7 boys and 3 girls) were investigated because of short stature or decreased growth velocity. At the time of the investigation, chronological age was $8.2 \pm$ $3.1 \mathrm{y}$; bone age, $6.9 \pm 3.2 \mathrm{y}$; height SD score, $-1.9 \pm 0.7$; and body mass index SD score, $-0.7 \pm 1.4$. Bone age was assessed by the method of Greulich and Pyle (5), height was expressed as SD score (6), and weight as body mass index SD score (7). All subjects underwent standard GH stimulation tests (arginine and insulin tolerance tests) before the study, which showed a normal GH response (peak $>10 \mathrm{ng} / \mathrm{mL}$ ). IGF-I serum concentrations were $34.6 \pm 10.9 \mathrm{nM}$ and those of IGFBP3 were $66.8 \pm 21.39 \mathrm{nM}$, both not statistically different from those seen in 24 prepubertal age-matched children, in whom IGF-I was $25.9 \pm 18.0 \mathrm{nM}$ and IGFBP3, $63.2 \pm 22.4 \mathrm{nM}$. Organic diseases, chromosomal aberrations, and other endocrine dysfunctions were ruled out. Thus, the subjects studied were considered to be affected by constitutional growth retardation. The study was approved by the Clinical Research Committee of the University of Pavia.

\section{Study Protocol}

Blood samples for the evaluation of GH were obtained every $30 \mathrm{~min}$, between $2000 \mathrm{~h}$ and $0800 \mathrm{~h}$ via an indwelling nonthrombogenic catheter inserted into an antecubital vein. After centrifugation, serum samples were stored at $-20^{\circ} \mathrm{C}$ until assayed.

Arbitrarily, the nighttime values were divided into two periods $(2000 \mathrm{~h}$ to $0200 \mathrm{~h}$ and $0200 \mathrm{~h}$ to $0800 \mathrm{~h}$ ) that were studied separately. The study was performed within 2 mo from the GH pharmacologic stimulation tests.

\section{Serum GH Concentrations}

By IFMA. Serum GH values were measured using a timeresolved IFMA (Delfia; LKB-Wallac, Turku, Finland) based on the direct sandwiching technique in which two MAb are directed against two separate, but unspecified, antigenic determinants on the hGH molecule. The IFMA is specific (detection limit $0.03 \mathrm{mIU} / \mathrm{L}$ ) for the $22-\mathrm{kD}$ form of hGH and has a low cross-reactivity with other GH molecular variants or pituitary hormones. The standards provided in the kits were calibrated against the First International Reference preparation of hGH $80 / 505$, in which $1 \mathrm{mg}=2.6 \mathrm{IU}$ of hGH. The intra- and interassay coefficients of variation were 2.1 to $5.0 \%$ and 4.2 to $6.3 \%$, respectively $(8,9)$.

By Nb2 cell bioassay. The bioassay was performed according to the method of Tanaka et al. (10), modified by Walker et al. (11) with further minor changes, as previously described (12). The intra- and interassay coefficients of variation were $6 \%$ and $7.6 \%$, respectively. The detection limit was $0.1 \mathrm{ng} / \mathrm{mL}$.

\section{IGF-I Measurement}

IGF-1 was measured by double-antibody RIA using immunochemicals and tracer provided by Medgenix (Fleurus, Bel- gium). The sensitivity of the assay was $150 \mathrm{pg} / \mathrm{mL}$; the intraand inter-assay coefficients of variation were $6 \%$ and $7.5 \%$, respectively. To avoid interference from binding proteins, samples were treated with acid ethanol.

\section{IGFBP-3 Measurement}

IGFBP-3 was measured by immunoassay using reagents and tracers provided by Bioclone Australia Pty Ltd. (Narrickville, NSW, Australia). The sensitivity of the assay was $3.5 \mathrm{ng} / \mathrm{mL}$; the intra- and interassay coefficients of variation were $4.25 \%$ and $6.6 \%$, respectively.

\section{Pulse Analysis}

The Pulsar program was used to quantify the pulse properties of the GH time series (13). The samples were analyzed for mean 12- and 6-h serum hormone concentrations, $\mathrm{AUCb}$, AUCo, number of significant pulses, mean pulse height, amplitude, area, length, and interpulse interval. The cut-off parameters G1-5 were set at $5,3,2,1.5$, and 1 times the intraassay SD as criteria for accepting peaks $1,2,3,4$, and 5 points wide, respectively. The smoothing time was set at half the total profile time, that is 6-h (12 points), and 3-h (6 points).

\section{Statistical Analysis}

Values are reported as mean \pm SEM. Statistical significance was assessed by $t$ test or Wilcoxon signed rank test, as appropriate.

\section{RESULTS}

GH secretion assessed by IFMA and GH bioactivity assessed by $\mathrm{Nb} 2$ assay were both found to be pulsatile (Fig. 1). Nighttime 6-h mean AUCb, AUCo, number of pulses, amplitude, height, length, area, interpulse interval, frequency, and mean concentration of $\mathrm{GH}$ assessed by both methods are

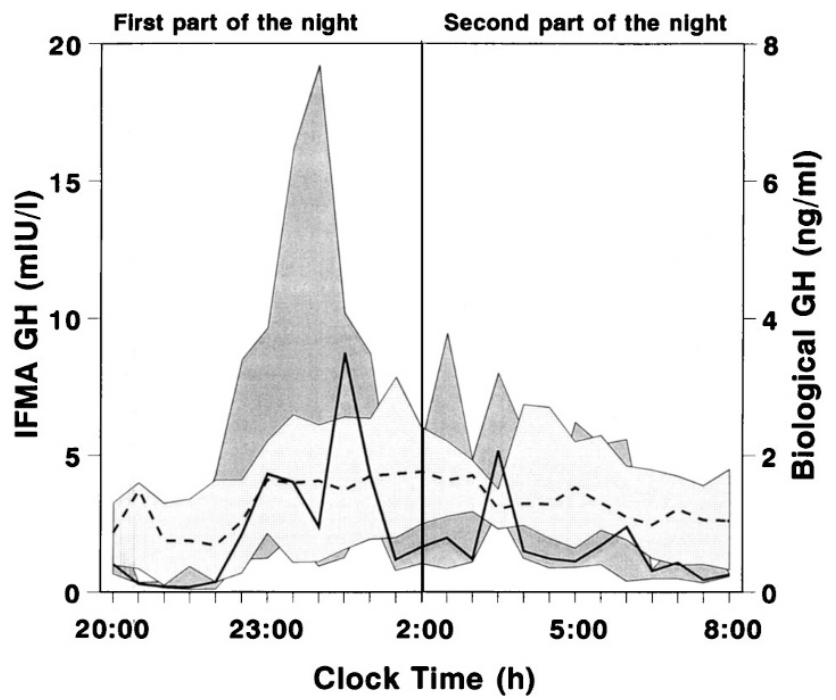

Figure 1. Twelve-hour immunoreactive (IFMA GH, dark gray area) and bioactive (biologic GH, light gray area) GH concentrations. The solid line represents the median of immunoreactive $\mathrm{GH}$ and the dotted line of the bioactive GH. The shaded areas delineate the lower and upper quartiles. 
Table 1. Properties of overnight pulsatile GH measured by an IFMA and by the Nb2 cell bioassay

\begin{tabular}{|c|c|c|c|c|}
\hline \multirow[b]{2}{*}{ Property } & \multicolumn{2}{|c|}{ GH IFMA (mIU/L) } & \multicolumn{2}{|c|}{ GH Biological Activity (ng/mL) } \\
\hline & $2000-0200 \mathrm{~h}$ & $200-0800 \mathrm{~h}$ & $2000-0200 \mathrm{~h}$ & $0200-0800 \mathrm{~h}$ \\
\hline $\mathrm{AUCb}$ & $9.67 \pm 2.17$ & $12.29 \pm 2.01$ & $1.11 \pm 0.52$ & $1.44 \pm 0.34$ \\
\hline Number of Pulses & $3.14 \pm 0.14$ & $3.57 \pm 0.20$ & $3.00 \pm 0.25$ & $3.83 \pm 0.60$ \\
\hline Pulse amplitude & $4.34 \pm 0.72$ & $4.62 \pm 0.87$ & $0.52 \pm 0.16$ & $0.64 \pm 0.09$ \\
\hline Pulse height & $7.77 \pm 0.1 .28$ & $4.83 \pm 0.33 *$ & $1.61 \pm 0.46$ & $1.69 \pm 0.32$ \\
\hline Interpulse interval (hr) & $2.25 \pm 0.17$ & $1.89 \pm 0.09$ & $1.76 \pm 0.23$ & $2.07 \pm 0.36$ \\
\hline Frequency (hr) & $0.57 \pm 0.02$ & $0.62 \pm 0.02$ & $0.56 \pm 0.06$ & $0.64 \pm 0.09$ \\
\hline Mean & $4.61 \pm 0.94$ & $2.68 \pm 0.27 *$ & $1.22 \pm 0.35$ & $1.36 \pm 0.29$ \\
\hline
\end{tabular}

$* p<0.05,0200-0800 \mathrm{~h}$ vs 2000-0200 h.

reported in Table 1. AUCb, AUCo, and mean concentration of bioactive $\mathrm{GH}$ were higher during the second half of the night compared with the first half, although the difference did not reach statistical significance. The mean number, amplitude, height, and length of pulses as well as the mean pulse area and frequency remained constant throughout the nighttime period.

Mean GH AUCo, height of the secretory pulses, and mean GH concentration assessed by IFMA were significantly higher during the first $6 \mathrm{~h}$, in comparison with the values obtained in the following period $(29.17 \pm 5.93$ versus $16.29 \pm 1.87$ $\mathrm{mIU} / \mathrm{L}, p<0.05 ; 4.61 \pm 0.94$ versus $2.68 \pm 0.27 \mathrm{mIU} / \mathrm{L}, p<$ $0.05 ; 7.77 \pm 1.28$ versus $4.83 \pm 0.33 \mathrm{mIU} / \mathrm{L}, p<0.05$, respectively). The mean number, amplitude, length, area, and frequency of secretory pulses remained constant throughout the night.

The GH IFMA/GH Nb2 ratio was significantly higher during the first $6 \mathrm{~h}$ of the night, in comparison with the values calculated for the following hours $(4.1 \pm 0.51$ versus $2.57 \pm$ $0.33, p<0.05$; Fig. 2).

\section{DISCUSSION}

The results of the present study indicate that the pattern of GH secretion assessed by an IFMA is different from that

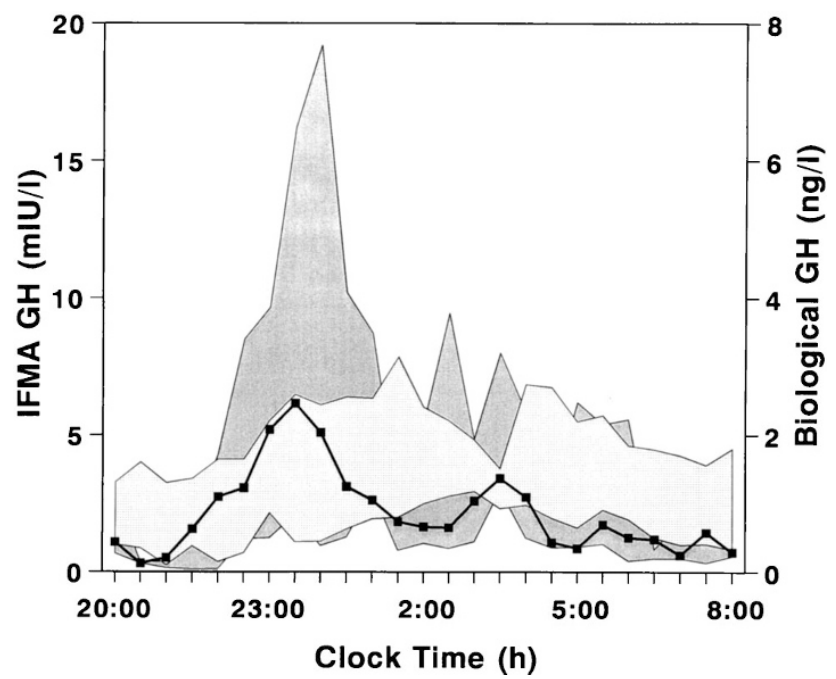

Figure 2. Twelve-hour immunoreactive (IFMA GH, dark gray area) and bioactive (biologic GH, light gray area) GH concentrations. The solid line represents the median of IFMA GH/biologic GH ratio computed at each time point. The shaded areas delineate the lower and upper quartiles. obtained by measuring the hormone biologic activity. During the initial hours of sleep, GH secretion measured by an IFMA showed a significant surge, whereas biologic activity was slightly increased during the second half of the night without showing, however, any significant modification throughout the entire period of observation. Thus, GH biologic activity remained constant throughout the night, whereas GH immunoreactivity exhibited a significant variation during the study period. A dissociation between GH bioactivity and immunoreactivity has previously been reported after pharmacologic stimulation. In one study, acute stimulation of GH secretion was accompanied by greater rises in bioactivity than immunoreactivity (14). In another report, after arginine and insulin stimulation, the responses of GH measured by RIA were 8-fold greater than those measured by bioassay, suggesting that the GH isoforms released by pharmacologic stimuli are not highly bioactive (15). Moreover, also in Turner syndrome, GH bioactivity has been described to be lower than that expected for immunoreactivity (16). To our knowledge, this is the first report of a dissociation between GH bioactivity and immunoreactivity measured in overnight samples and in physiologic conditions.

The IFMA assay recognizes mostly the 22-kD form in its bound and unbound form (i.e. total circulating $\mathrm{GH}$ ), whereas the $\mathrm{Nb} 2$ cell assay evaluates GH bioactivity at the target tissue level, i.e. the effect of the different $\mathrm{GH}$ isoforms, modulated by the binding proteins. A limitation of this assay is that it measures lactogenic, and not somatogenic GH bioactivity. However, lactogenic GH bioactivity, evaluated after s.c. GH administration, shows a good correlation with the growth response during the first year of GH therapy (17), and thus can be used as an indirect measurement of somatogenic activity.

The dissociation between GH bioactivity and immunoreactivity might be interpreted as the result of a different clearance of the various GH molecules. During the period of maximal immunoreactive GH surge, observed during the first part of the night, the $22-\mathrm{kD}$ form could be cleared more rapidly from the circulation than the $20-\mathrm{kD}$ form (18) or other oligomers (19, 20 ), allowing the $20-\mathrm{kD}$ form to circulate for a longer period of time. The latter, because of its long half-life (18), was shown to have a good growth-promoting activity in the rat (21) despite a decreased affinity for $\mathrm{GH}$ receptors (22). The $20-\mathrm{kD}$ isoform is recognized by the $\mathrm{Nb} 2$ cell assay (23), and thus could account for the sustained GH bioactivity after the IFMA GH 
surge. However, it ha recently been shown that the percentage of the $20-\mathrm{kD}$ isoform does not change after pharmacologic stimulation or during nocturnal sleep (24).

Another possible explanation of our results is that the two assays might recognize different dimers of GH (25). It has been shown, in fact, that an acidic $20-\mathrm{kD} / 22-\mathrm{kD}$ heterodimer of $\mathrm{GH}$ is 2.5 times more potent than the $22-\mathrm{kD}$ molecule alone in stimulating $\mathrm{Nb} 2$ cells, although these two variants show a similar immunoreactivity (26).

Alternatively, during the first part of the night there might be an increment of both the GH bound to binding proteins and its free form, which are both recognized by the two assays. Later on, when the IFMA GH troughs are observed, the dissociation of $\mathrm{GH}$ from the binding proteins could maintain a relatively constant level of free $\mathrm{GH}$ that, in turn, maintains $\mathrm{GH}$ bioactivity constant. GH dissociation, in fact, was shown to maintain high levels of GH delivered to target tissues during secretory troughs (1).

In conclusion, a dissociation between GH bioactivity and immunoreactivity is present in physiologic conditions, indicating that standard GH measurements do not provide any information on the interaction between the hormone and its receptors in target tissues and on the effect of the different $\mathrm{GH}$ isoforms. This dissociation would explain why some short children grow poorly despite the presence of normal immunoreactive $\mathrm{GH}$ levels, and why in tall children IGF-I levels are higher than in normal-height peers (27) in the absence of high GH levels.

\section{REFERENCES}

1. Lim L, Spencer SA, McKay P, Waters MJ 1990 Regulation of growth hormone (GH) bioactivity by a recombinant human GH-binding protein. Endocrinology 127:12871291

2. Hindmarsh PC, Smith PJ, Pringle PJ, Brook CGD 1987 The relationship between height velocity and growth hormone secretion in short pre-pubertal children Clin Endocrinol (Oxf) 27:581-591

3. Hindmarsh PC, Matthews DR, Stratton I, Pringle PJ, Brook CGD 1992 Rate of change (modulation) of serum growth hormone concentrations is a more important factor in determining growth rate than duration of exposure. Clin Endocrinol (Oxf) 36:165-170

4. Isgaard J, Carlsson L, Isaksson OG, Jansson JO 1988 Pulsatile intravenous growth hormone $(\mathrm{GH})$ infusion to hypophysectomized rats increases insulin-like growth factor I messenger ribonucleic acid in skeletal tissues more effectively than continuous GH infusion. Endocrinology 123:2605-2610

5. Greulich WW, Pyle SL 1969 Radiographic Atlas of Skeletal Development of the Hand and Wrist, 2nd ed. Stanford University Press, Stanford, CA

6. Tanner JM, Whitehouse RH, Takaishi M 1966 Standards from birth to maturity for height, weight, height velocity and weight velocity: British children. Arch Dis Child 41:613-635
7. Rolland-Cachera MF, Cole TJ, Sempé M, Tichet J, Rossignol C, Charraud A 1991 Body mass index variations: centile from birth to 87 years. Eur J Clin Nutr 45:13-21

8. Albertsson-Wikland K, Jansson C, Rosberg S, Novamo A 1993 Time-resolved immunofluorometric assay of human growth hormone. Clin Chem 39:1620-1625

9. Rott AW, Duckett GE, Geiszler JE, Hu CS, Bercu BB 1997 Evaluation of the clinical utility of the ultrasensitive immunofluorometric assay for growth hormone $(\mathrm{GH})$ and of the cortisol secretory pattern in prediction of the linear growth response to treatment with GH. J Pediatr Endocrinol Metab 10:3-10

10. Tanaka T, Shiu RPC, Gout PJ, Beer CT, Noble RL, Friesen HG1980 A new sensitive and specific bioassay for lactogenic hormones: measurements of prolactin and growth hormone in human serum. J Clin Endocrinol Metab 51:1058-1063

11. Walker A, Croze F, Friesen HG 1987 A serum-free medium for culturing lactogen dependent and autonomous Nb2 node lymphoma cells. Endocrinology 120:23892397

12. Bozzola M, Radetti G, Buzi F, Tonini G, Moretta A, Autelli M, Aglialoro A, Rondini G, Barreca A 1999 Growth hormone bioactivity and immunoactivity in tall children. J Endocrinol Invest 22:541-546

13. Merriam GR, Watcher KW 1982 Algorithms for the study of episodic hormone secretion. Am J Physiol 243:E310-E318

14. Dattani MT, Hindmarsh PC, Pringle PJ, Brook CGD, Marshall NJ 1995 The measurement of growth hormone bioactivity in patient serum using an eluted stain assay. J Clin Endocrinol Metab 9:2675-2683

15. Foster CM, Borondy M, Padmanabhan V, Schwartz J, Kletter GB, Hopwood NJ, Beitins IZ 1993 Bioactivity of human growth hormone in serum: validation of an in vitro bioassay. Endocrinology 132:2073-2081

16. Foster CM, Borondy M, Markovs ME, Hopwood NJ, Kletter GB, Beitins IZ 1994 Growth hormone bioactivity in girls with Turner's syndrome: correlation with insulin-like growth factor 1. Pediatr Res 35:218-222

17. Bozzola M, Radetti G, Pagani S, Draghi M, Aimaretti G, Rondini G 1999 The level of bioavailable growth hormone $(\mathrm{GH})$ after the first $\mathrm{GH}$ injection predicts the first year's growth response in GH-deficient children. J Endocrinol Invest 22:790-795

18. Baumann G, Stolar MW, Buchanan TA 1985 Slow metabolic clearance of the 20,000-dalton variant of human growth hormone: implications for biological activity. Endocrinology 117:1309-1313

19. Baumann G, Stolar MW, Buchanan TA 1986 The metabolic clearance, distribution, and degradation of dimeric and monomeric growth hormone (GH): implications for the pattern of circulating GH forms. J Clin Endocrinol Metab 119:1497-1501

20. Hendricks CM, Eastman RC, Takeda S, Asakawa K, Gorden P 1985 Plasma clearance of intravenously administered pituitary human growth hormone: gel filtration studies of heterogeneous components. J Clin Endocrinol Metab 60:864-867

21. Lewis UJ, Dunn JT, Bonewald LF, Seavey BK, Vanderlaan WP 1978 A naturally occurring variant of growth hormone. J Biol Chem 253:2679-2687

22. Sigel MB, Thorpe NA, Kobrin MS, Lewis UJ, VanderLaan WP 1981 Binding characteristics of a biologically active variant of human growth hormone (20K) to growth hormone and lactogen receptors. Endocrinology 108:1600-1603

23. Emoto N, Tsushima T, Shizume K, Tanaka T, Saji M, Ohba Y, Wakai K, Arai M, Ohmura E 1987 Biological activities of human growth hormone and its derivatives estimated by measuring DNA synthesis in $\mathrm{Nb} 2$ node rat lymphoma cells. Acta Endocrinol (Copenh) 114:283-291

24. Ishikawa M, Yokoya S, Tachibana K, Hasegawa Y, Yasuda T, Tokuhiro E, Hashimoto Y, Tanaka T 1999 Serum level of 20-kilodalton human growth hormone (GH) are parallel those of 22-kilodalton human GH in normal and short children. J Clin Endocrinol Metab 84:98-104

25. Singh RNP, Seavey BK, Lewis UJ 1974 Heterogeneity of human growth hormone. Endocr Res Commun 1:449-464

26. Brostedt P, Luthman M, Wide L, Werner S, Roos P 1990 Characterization of dimeric forms of human pituitary growth hormone by bioassay, radioreceptor assay, and radioimmunoassay. Acta Endocrinol (Copenh) 122:241-248

27. Gourmelen M, Le Bouc Y, Girard F, Binoux M 1984 Serum levels of insulin-like growth factor (IGF) and IGF binding protein in constitutionally tall children and adolescents. J Clin Endocrinol Metab 59:1197-1203 